\title{
Faktor Risiko Obstructive Sleep Apnea pada Anak Sindrom Down
}

Dewi Kartika Suryani, Bambang Supriyatno, Mulya Rahma Karyanti, Zakiudin Munasir, Sudung O. Pardede, Dina Muktiarti

Departemen Ilmu Kesehatan Anak Fakultas Kedokteran Universitas Indonesia / Rumah Sakit Dr. Cipto Mangunkusumo, Jakarta

Latar belakang. Sindrom Down merupakan kelainan kromosom tersering. Anak dengan sindrom Down (SD) di berbagai negara memiliki beberapa faktor risiko terhadap OSA dengan prevalensi antara 30\%-60\%, dibandingkan 0,7\%-2\% pada populasi umum. Hingga saat ini belum ada data mengenai OSA pada anak sindrom Down di Indonesia.

Tujuan. Mengidentifikasi prevalensi OSA pada anak sindrom Down dan menganalisis hubungan antara habitual snoring, obesitas, penyakit alergi di saluran napas, hipertrofi tonsil, dan hipertrofi adenoid sebagai faktor risiko OSA pada anak sindrom Down.

Metode. Penelitian potong lintang dilakukan pada anak sindrom Down berusia 3-18 tahun yang tergabung dalam Yayasan POTADS. Penelitian dilakukan di Poliklinik Respirologi IKA FKUI RSCM dari bulan Juli 2016 hingga Juli 2017. Penegakan diagnosis OSA menggunakan nilai batas $\mathrm{AHI} \geq 3$ pada pemeriksaan poligrafi. Faktor- risiko yang dianggap berpengaruh dianalisis secara multivariat. Hasil. Penelitian dilakukan terhadap 42 subjek dengan hasil prevalensi OSA pada anak dengan SD 61,9\%. Sebesar 42,9\% merupakan OSA derajat ringan, $14,3 \%$ OSA sedang, dan 4,8\% OSA berat. Pada analisis multivariat didapatkan faktor risiko yang bermakna yaitu habitual snoring ( $\mathrm{p}=0,022$ dan $P R$ 8,85; IK 1,37-57) dan hipertrofi adenoid ( $\mathrm{p}=0,006$ dan $P R$ 12,93; IK 2,09-79).

Kesimpulan. Prevalensi OSA pada anak sindrom Down sebesar 61,9\%. Faktor risiko yang bermakna yaitu habitual snoring dan hipertrofi adenoid. Sari Pediatri 2019;20(5):295-302

Kata kunci: OSA, sindrom Down, faktor risiko

\section{Risk Factor of Obstructive Sleep Apnea in Children with Down Syndrome}

\author{
Dewi Kartika Suryani, Bambang Supriyatno, Mulya Rahma Karyanti, Zakiudin Munasir, Sudung O. Pardede, Dina Muktiarti
}

Background. Down syndrome (DS) is the most common chromosomal disorder. Children with DS have predisposing factors to OSA with prevalence $30-60 \%$, compared with $0.7-2 \%$ in the general child population. Until now there is no data about OSA in DS children in Indonesia.

Objective. To identify the prevalence of OSA in DS and to analyze the effect of habitual snoring, obesity, airways allergic diseases, tonsillar hypertrophy, and adenoid hypertrophy as a risk factor for OSA.

Method. This is a cross-sectional study, held in Respirology Clinic of IKA-FKUI RSCM Jakarta from July 2016 to July 2017 . Subjects in this study were DS children aged 3 - 18 years who are members of the Foundation POTADS (Parents Association of Children with Down Syndrome). OSA was diagnosed by polygraphy examination with cutoff AHI $\geq 3$. The risk factors that are considered important are then analyzed multivariately.

Results. OSA prevalence among 42 subjects are 61,9\%. A Degree of OSA are $42.9 \%$ mild, 14.3\% moderate, and $4.8 \%$ severe. In the multivariate analysis, the significant risk factor are habitual snoring ( $\mathrm{p}=0,022$ and $P R 8,85$; CI 1,37-57) and adenoid hypertrophy ( $\mathrm{p}=0,006$ and PR 12,93; CI 2,09-79).

Conclusion. Prevalence of OSA in DS children is 61,9\%. The significant risk factors is habitual snoring and adenoid hypertrophy. Sari Pediatri 2019;20(5):295-302

Keywords: OSA, Down syndrome, risk factors

Alamat korespondensi: Dewi Kartika Suryani. Departemen Ilmu Kesehatan Anak Fakultas Kedokteran Universitas Indonesia Jalan Salemba Raya no 6, Jakarta, 10430, Indonesia Email: suryani.deka@gmail.com 
O bstructive sleep apnea (OSA) merupakan gangguan pernapasan selama tidur yang ditandai dengan periode peningkatan resistensi jalan napas atas dan episode berulang obstruksi jalan napas atas, baik parsial dan atau komplit,sehingga menyebabkan terganggunya ventilasi dan oksigenasi normal selama tidur, begitu pula pola tidur normal. ${ }^{1,2}$ Beberapa penelitian menunjukkan faktor risiko OSA pada anak, yaitu obesitas, penyakit alergi di saluran napas, hipertrofi adenoid, tonsil, dan disproporsi kraniofasial seperti sindrom Down (SD)..$^{3-5}$

Sindrom Down merupakan kelainan kromosom tersering pada anak dengan insiden 1 dari 800 kelahiran hidup. ${ }^{6}$ Berdasarkan data Riset Kesehatan Dasar (RISKESDAS) tahun 2013, jumlah anak dengan SD di Indonesia mencapai 300.000 , sedangkan jumlah pasien tahun 2005 hingga 2014 di Rumah Sakit Cipto Mangunkusumo (RSCM) tercatat 589 anak. $^{7}$ Anak dengan SD memiliki faktor predisposisi terhadap sejumlah masalah kesehatan yang memengaruhi perkembangan dan kualitas hidup mereka. ${ }^{8-10}$ Perkiraan prevalensi OSA 30\%-60\% dibandingkan dengan populasi anak umum sebesar $0,7 \%-2 \% .{ }^{11}$

Pada anak dengan SD, OSA adalah kondisi kompleks dan multifaktorial. Faktor risiko anatomi, antara lain, hipoplasia midfacial dan mandibular, nasofaring sempit, mikrognatia, makroglosia, hipertrofi adenoid dan tonsil, serta palatum yang pendek. Kelainan anatomi ini disertai dengan hipotonia umum, infeksi respiratorik berulang akibat imaturitas sistem imun, disfungsi tiroid, dan kecenderungan obesitas merupakan faktor penyebab obstruksi saluran napas atas. ${ }^{12-14}$

Potensi dampak negatif OSA terhadap kesehatan anak, yaitu gagal tumbuh, hipertensi pulmonal, gangguan tingkah laku, dan fragmentasi tidur yang memengaruhi aktivitas siang hari dan fungsi kognitif. Pada anak dengan SD, kondisi medis, gangguan kognitif, emosi, dan tingkah laku menyebabkan mereka lebih rentan terhadap dampak negatif OSA. ${ }^{15-17}$

Spektrum gangguan tidur bervariasi mulai dari kondisi ringan, yaitu mendengkur primer, upper airway resistance syndrome (UARS) hingga OSA. ${ }^{18}$ Apabila mendengkur lebih dari 3 kali seminggu (habitual snoring) maka seringkali terjadi OSA. ${ }^{4,19}$ Sebagian besar orangtua beranggapan bahwa gangguan tidur adalah hal normal pada anak dengan SD, sekitar 69\% orangtua melaporkan anaknya tidak mengalami gangguan tidur, padahal 57\% di antaranya menunjukkan hasil abnormal pada uji tidur. ${ }^{11}$ Korelasi lemah antara laporan orangtua mengenai gejala OSA dengan hasil uji tidur menjadi alasan American Academy of Pediatrics (AAP) merekomendasikan pemeriksaan polisomnografi (PSG) pada semua anak dengan SD mulai usia 4 tahun atau lebih dini bila terdapat gejala mendengkur. ${ }^{9,11}$

Meskipun prevalensi OSA tinggi pada anak dengan $\mathrm{SD}$, hingga saat ini belum ada data mengenai OSA pada anak dengan SD di Indonesia. Salah satu kendala yang dihadapi yaitu modalitas diagnostik OSA yaitu PSG belum tersedia secara merata di seluruh tingkat pelayanan kesehatan. Diagnosis OSA dan tata laksana terhadap faktor risiko sangat penting untuk mencegah komplikasi yang dapat menurunkan kualitas hidup anak dengan SD.

Tujuan dari penelitian ini adalah mendapatkan data prevalensi anak SD dengan OSA dan mengidentifikasi faktor risiko OSA pada anak dengan SD.

\section{Metode}

Penelitian ini merupakan metode potong lintang (cross sectional) deskriptif analitik. Penelitian dilaksanakan sejak lolos kaji etik dari Panitia Tetap Etik Penelitian Kedokteran/Kesehatan Fakultas Kedokteran Universitas Indonesia (FKUI), yaitu pada Juli 2016 sampai dengan 29 Juli 2017. Subjek penelitian adalah anak dengan SD berusia 3 sampai 18 tahun yang berdomisili di Jakarta, Bogor, Depok, Tangerang dan Bekasi yang tergabung dalam yayasan Persatuan Orangtua Anak dengan Down Syndrome (POTADS). Kriteria inklusi adalah diagnosis SD pada subjek telah dikonfirmasi melalui pemeriksaan analisis kromosom dan persetujuan inform consent tertulis dari orangtua. Subjek dieksklusi bila sedang mengalami infeksi saluran napas atas maupun bawah dalam 14 hari sebelum pemeriksaan radiologi lateral adenoid maupun pemeriksaan poligrafi, telah dilakukan operasi tonsilektomi dan atau adenoidektomi, memiliki kelainan anatomis selain anomali kraniofasial yang dapat memengaruhi hasil pemeriksaan poligrafi, misalnya laringomalasia, penyakit jantung bawaan yang belum dikoreksi, mengalami kelainan neurologis, misalnya palsi serebral, epilepsi, hipertiroid atau hipotiroid, tidak tuntas mengikuti rangkaian pengambilan data.

Jumlah sampel yang diambil berdasarkan prevalensi OSA pada anak dengan SD, yaitu 42 orang. Peneliti bekerja sama dengan Persatuan Orangtua Anak 
dengan Down Syndrome (POTADS) untuk menjaring para orangtua di komunitas yang bersedia anaknya ikut serta dalam penelitian melalui pesan singkat dan penjelasan langsung kepada orangtua melalui seminar OSA. Orangtua yang memiliki anak usia 3 sampai 18 tahun yang memenuhi kriteria inklusi diambil sebagai subjek penelitian. Pada saat pasien datang ke Poliklinik Respirologi Kiara RSCM dilakukan pemeriksaan fisis antropometri dengan menggunakan timbangan merek SECA ${ }^{\circledR}$ dan pemeriksaan ukuran tonsil. Tahap selanjutnya adalah mencatat identitas, jenis kelamin dan usia. Wawancara terstruktur oleh peneliti dilakukan dengan kuesioner yang ditanyakan pada orangtua mengenai keluhan mendengkur atau kesulitan bernapas saat tidur, dan penyakit alergi di saluran napas yang diderita. Setelah anamnesis dilakukan pemeriksaan foto lateral adenoid di Poli Pencitraan Kiara RSCM. Tahap selanjutnya peneliti membuat perjanjian dengan orangtua untuk pemeriksaan uji tidur di rumah pasien.
Selama dilakukan pemeriksaan poligrafi, aktivitas subjek selama tidur terekam oleh alat poligrafi. Semua pasien mendapatkan tata laksana sesuai prosedur standar untuk pemeriksaan poligrafi.

Pemeriksaan dianggap berhasil bila alat terpasang dan aktivitas tidur terekam setidaknya selama 4 jam. Pemeriksaan dianggap tidak tuntas dan pasien akan dieksklusi apabila telah dilakukan 2 kali pemeriksaan pada subjek yang sama tetapi aktivitas tidur terekam kurang dari 4 jam. Pasien yang didiagnosis akan ditatalaksana sesuai prosedur oleh konsultan dari divisi Respirologi. Hasil penelitian diolah dengan menggunakan SPSS 22.0.

\section{Hasil}

Data karakteristik subjek penelitian berupa jenis kelamin, usia, proporsi gizi lebih dan obesitas, penyakit

Tabel 1. Karakteristik subjek penelitian

\begin{tabular}{lc}
\hline Karakteristik & $\mathrm{n}(\%)$ \\
\hline Jenis kelamin & $19(45,2)$ \\
Lelaki & $23(54,8)$ \\
Perempuan & $7,5( \pm 3,48)$ \\
Usia, rerata $( \pm$ SD) tahun & $28(66,7)$ \\
$\quad-3-8$ & $14(33,3)$ \\
$\quad-8$ & $15,75(13,10-30,50)$ \\
IMT, nilai tengah (kisaran) & $4(9,5)$ \\
$\quad$ Gizi lebih dan obesitas (p85-p95 dan $\geq \mathrm{p} 95)$ & $38(90,5)$ \\
$\quad$ Baik (p5-p85) & \\
Penyakit alergi di saluran napas & $7(16,7)$ \\
$\quad$ Ya & $35(83,3)$ \\
Tidak & \\
Pembesaran tonsil & $16(38,1)$ \\
$\quad \geq$ T3 & $26(61,9)$ \\
$\quad<$ T3 & \\
Pembesaran adenoid & $20(47,6)$ \\
Ya & $22(52,4)$ \\
Tidak & $0,66(0,34-0,84)$ \\
ANR, nilai tengah (kisaran) & \\
Pembesaran adenoid dan tonsil & $13(31)$ \\
Ya & $29(69)$ \\
Tidak & \\
Mendengkur & $4(9,5)$ \\
Occasional snoring & $18(42,9)$ \\
Habitual Snoring & $20(47,6)$ \\
Tidak & \\
\hline Ning &
\end{tabular}

Nilai \% dihitung berdasarkan jumah total subjek penelitian (n total=42) 
alergi di saluran napas, mendengkur, hipertrofi tonsil dan hipertrofi adenoid tertera pada Tabel 1. Perbandingan antara jenis kelamin lelaki dibandingkan perempuan adalah 1:1,2. Rerata usia subjek adalah 7,5 tahun, usia paling muda 3 tahun dan tertua 16 tahun 5 bulan. Sebagian besar tipe kelainan kromosom, yaitu trisomi 21, hanya 1 subjek jenis mosaik, dan 1 subjek jenis translokasi.

Sebanyak $22(52,4 \%)$ subjek mengalami keluhan mendengkur, 18 (42,9\%) di antaranya mendengkur lebih dari 3x seminggu (habitual snoring), sedangkan $4(9,5 \%)$ mengalami occasional snoring bila sedang pilek atau terlalu lelah, dan $20(47,6 \%)$ subjek tidak dikeluhkan mendengkur sama sekali.

Nilai tengah IMT subjek $15,7 \mathrm{~kg} / \mathrm{m}^{2}$ dengan nilai terendah $13,1 \mathrm{~kg} / \mathrm{m}^{2}$ dan nilai tertinggi $30,5 \mathrm{~kg} / \mathrm{m}^{2}$. Hanya 1 subjek yang termasuk dalam kategori obesitas, 3 termasuk dalam kategori gizi lebih, sedangkan sisanya 38 subjek kategori gizi baik $(90,5 \%)$. Hanya 7 dari 42 subjek $(16,7 \%)$ yang memiliki penyakit alergi di saluran napas berupa rinitis alergi dan tidak ada yang memiliki riwayat asma. Pembesaran kelenjar tonsil didapatkan pada $16(38,1 \%)$ subjek. Sebagian besar pembesaran tonsil, yaitu ukuran T3, hanya 2 subjek yang mengalami kissing tonsil (T4-T4). Pembesaran kelenjar adenoid didapatkan pada 20 (47,6\%) subjek, nilai tengah ANR 0,66 dengan nilai terendah 0,34 dan tertinggi 0,84 .

Dari total 42 subjek penelitian, derajat OSA berdasarkan pemeriksaan uji tidur dengan nilai batas AHI $\geq 3$ sebanyak 26 subjek, terdiri atas 18 derajat

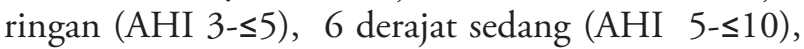
dan 2 derajat berat $(A H I>10)$. Sementara yang tidak OSA sebanyak 16 subjek.

Profil uji tidur dengan pemeriksaan poligrafi tertera pada Tabel 2. Nilai tengah AHI, indeks apnea, indeks hipopnea, saturasi terendah, dan saturasi dasar berturut-turut adalah 3,15; 1,4; 1,45; 79,5; dan 99 .

Tabel 2. Gambaran hasil uji tidur

\begin{tabular}{ll}
\hline Parameter respiratori & Nilai tengah (kisaran) \\
\hline AHI, kali/jam & $3,15(0,2-28,6)$ \\
Indeks apnea, kali/jam & $1,4(0-13,2)$ \\
Indeks hipopnea, kali/jam & $1,45(0-15,4)$ \\
Saturasi terendah, (\%) & $79,5(51-94)$ \\
Saturasi dasar, (\%) & $99(89-100)$ \\
\hline
\end{tabular}

Nilai \% dihitung berdasarkan jumah total subjek penelitian (n total $=42$ )
Nilai terendah AHI adalah 0,2 kali/jam dan nilai tertinggi AHI 28,6 kali/jam. Nilai terendah indeks apnea adalah $0 \mathrm{kali} / \mathrm{jam}$ dan nilai tertinggi indeks apnea adalah $13,2 \mathrm{kali} / \mathrm{jam}$. Nilai terendah saturasi terendah adalah $51 \%$ dan nilai tertinggi saturasi terendah adalah $94 \%$. Nilai terendah saturasi dasar adalah $89 \%$ dan nilai tertinggi adalah $100 \%$.

Analisis bivariat menggunakan uji statistik yang sesuai. Variabel kategorik terhadap kategorik diuji dengan menggunakan tabel $2 \times 2$ dengan Chi-Square atau Fisher. Hasil analisis bivariat terhadap uji tidur tertera pada Tabel 3. Berdasarkan analisis bivariat, terdapat tiga determinan dengan nilai $\mathrm{p}<0,05$ yaitu habitual snoring, hipertrofi tonsil, dan hipertrofi adenoid terhadap OSA. Faktor-faktor atau determinan yang mempunyai nilai $\mathrm{p}<0,25$ pada analisis bivariat dimasukkan dalam tabel analisis multivariat.

Analisis multivariat yang digunakan adalah analisis regresi logistik dengan menggunakan metode backward:LR pada variabel bebas dengan $\mathrm{p}<0,25$. Faktor yang diteliti terhadap OSA yang dimasukkan ke dalam analisis multivariat antara lain habitual snoring, alergi, hipertrofi tonsil, dan hipertrofi adenoid. Hasil analisis multivariat terhadap OSA mendapatkan dua determinan dengan nilai $\mathrm{p}<0,05$, yaitu hipertrofi adenoid dengan rasio prevalensi 12,93 (IK 2,01-79,95) dan habitual snoring dengan prevalence ratio 8,85 (IK 1,37-57).

\section{Pembahasan}

Pemeriksaan uji tidur idealnya melalui pemeriksaan PSG yang dilakukan di rumah sakit (RS) dengan petugas medis yang mengawasi. Terdapat beberapa kendala pemeriksaan PSG, yaitu mahal, memerlukan koordinasi anak yang sangat baik, belum ada RS yang memiliki laboratorium tidur, dan mahalnya biaya rawat inap di RS. Penelitian ini menggunakan uji tidur poligrafi di rumah subjek dengan pertimbangan bersifat mudah untuk digunakan. Orangtua dapat diajarkan untuk mengawasi dan memasang kembali bila alat terlepas. Penelitian ini merupakan penelitian pertama yang menilai gangguan tidur pada anak dengan SD di Indonesia.

Penelitian ini mendapatkan 26 (61,9\%) subjek memiliki hasil uji tidur abnormal berupa OSA dengan nilai batas $\mathrm{AHI} \geq 3$. Mayoritas derajat OSA berupa OSA derajat ringan dengan $\mathrm{AHI}$ 3,1-5 kali/jam sebanyak 18 
Tabel 3. Analisis bivariat faktor yang diteliti terhadap OSA

\begin{tabular}{|c|c|c|c|c|}
\hline Faktor yang diteliti & $\begin{array}{c}\text { OSA } \\
(\mathrm{n}=26)\end{array}$ & $\begin{array}{c}\text { Tidak OSA } \\
(\mathrm{n}=16)\end{array}$ & Nilai p & Rasio prevalensi (IK 95\%) \\
\hline \multicolumn{5}{|l|}{ Usia, $\mathrm{n}(\%)$, tahun } \\
\hline $3-8$ & $18(64,3)$ & $10(35,7)$ & $0,653^{\mathrm{a}}$ & $1,35(0,36-5)$ \\
\hline$>8$ & $8(57,1)$ & $6(42,9)$ & & \\
\hline \multicolumn{5}{|l|}{ Jenis kelamin, $\mathrm{n}(\%)$} \\
\hline Lelaki & $12(63,2)$ & $7(36,8)$ & $0,879^{a}$ & $1,1(0,31-3,86)$ \\
\hline Perempuan & $14(60,9)$ & $9(39,1)$ & & \\
\hline \multicolumn{5}{|l|}{ IMT, n (\%) } \\
\hline Gizi lebih/obesitas & $3(75)$ & $1(25)$ & $0,505^{b}$ & $1,96(0,18-20,61)$ \\
\hline Baik & $23(60,5)$ & $15(39,5)$ & & \\
\hline \multicolumn{5}{|c|}{ Penyakit alergi di saluran napas, n (\%) } \\
\hline $\mathrm{Ya}$ & $6(85,7)$ & $1(14,3)$ & $0,161^{\mathrm{b}}$ & $4,5(0,49-41,45)$ \\
\hline Tidak & $20(57,1)$ & $15(42,9)$ & & \\
\hline \multicolumn{5}{|l|}{ Hipertrofi tonsil, n (\%) } \\
\hline $\mathrm{Ya}$ & $15(93,8)$ & $1(6,3)$ & $0,001^{\mathrm{a}}$ & $20,4(2,34-178)$ \\
\hline Tidak & $11(42,3)$ & $15(57,7)$ & & \\
\hline \multicolumn{5}{|c|}{ Hipertrofi adenoid, n (\%) } \\
\hline $\mathrm{Ya}$ & $18(90)$ & $2(10)$ & $0,000^{\mathrm{a}}$ & $15,75(2,87-86)$ \\
\hline Tidak & $8(36,4)$ & $14(63,6)$ & & \\
\hline \multicolumn{5}{|c|}{ Habitual snoring, n (\%) } \\
\hline Ya & $16(88,9)$ & $2(11,1)$ & $0,002^{\mathrm{a}}$ & $11,2(2,08-60)$ \\
\hline Tidak & $10(41,7)$ & $14(58,3)$ & & \\
\hline
\end{tabular}

${ }^{\bar{a}}$ Chi square; ${ }^{\mathrm{b}}$ Fisher

Tabel 4. Analisis multivariat faktor yang diteliti terhadap OSA

\begin{tabular}{llcc}
\hline & Variabel & Nilai p & Rasio prevalensi $(\mathrm{IK})$ \\
\hline Model 1 & Hipetrofi tonsil & 0,227 & $6,467(0,31-133,78)$ \\
& Hipertrofi adenoid & 0,019 & $18,01(1,598-203)$ \\
& Penyakit alergi di saluran napas & 0,150 & $0,064(0,02-2,70)$ \\
\multirow{2}{*}{ Model 2 } & Habitual snoring & 0,071 & $7,11(0,84-59,94)$ \\
& Hipertrofi adenoid & 0,008 & $24,10(2,29-254,14)$ \\
& Penyakit alergi di saluran napas & 0,257 & $0,146(0,005-4,05)$ \\
\multirow{2}{*}{ Model 3 3} & 0,014 & $11,68(1,65-82,34)$ \\
& Habitual snoring & 0,006 & $12,93(2,09-79,95)$ \\
& Hipertrofi adenoid & 0,022 & $8,85(1,37-57)$ \\
\hline
\end{tabular}

$(42,9 \%)$ subjek, derajat sedang $6(14,3 \%)$, dan derajat berat $2(4,8 \%)$ subjek. Hasil ini tidak jauh berbeda dengan penelitian sebelumnya yang dilakukan oleh Miguel $\mathrm{dkk}^{20}$ menggunakan uji poligrafi pada anak dengan SD dengan rerata usia 7,9 tahun (1-18 tahun), yaitu 54,6\%.

Dyken $\mathrm{dkk}^{21}$ mendapatkan prevalensi OSA 79\% pada 19 anak dengan SD usia 3-18 tahun (rerata usia 9,1 tahun). Fitzgerald $\mathrm{dkk}^{22}$ menggunakan subjek anak dengan SD usia 0-18 tahun (rerata usia 4,9 tahun) dengan klinis mendengkur, yaitu $98 \%$, terdiri atas $97 \%$ derajat ringan-sedang (AHI 1-10), 1\% derajat berat. $\mathrm{Ng}^{23}$ membandingkan 22 anak dengan SD di Singapura rerata usia 8 tahun dengan anak OSA non-SD yang dirujuk untuk pemeriksaan PSG karena keluhan mendengkur pada periode yang sama sebagai kelompok kontrol. Diagnosis OSA menggunakan nilai batas AHI >1,5 dan didapatkan prevalensi OSA sebesar 
59\% pada SD dan 32\% pada kelompok kontrol. Austeng $\mathrm{dkk}^{24}$ mendapatkan prevalensi OSA sebesar $96 \%$ pada 29 anak dengan SD usia 8 tahun, dan sebesar $66 \%$ diantaranya memiliki AHI $>5$.

Penelitian oleh Maris dkk ${ }^{25}$ melibatkan 216 anak dengan SD, pemeriksaan PSG berhasil dilakukan pada 122 anak dengan nilai tengah usia 5 tahun $(2,8-10,5)$. Prevalensi OSA menggunakan nilai batas AHI $\geq 2$, yaitu $66,4 \%$. Perbedaan prevalensi pada beberapa penelitian dapat disebabkan perbedaan kriteria diagnostik yang digunakan untuk diagnosis OSA, kriteria inklusi subjek, kelompok usia, dan jumlah subjek dengan obesitas.

Rerata nilai AHI pada penelitian ini 4,15 kali/jam. Rerata nilai AHI pada penelitian Miguel $\mathrm{dkk}^{20}$ yang menggunakan poligrafi $6,18 \mathrm{kali} / \mathrm{jam}$. Nilai tengah AHI pada penelitian ini $3,15 \mathrm{kali} / \mathrm{jam}(0,2-28,6)$. Penelitian lain mendapatkan nilai tengah AHI $6^{21}$ dan $1,8,4,3 \mathrm{kali} / \mathrm{jam}^{26} \mathrm{dan}$ lebih tinggi pada anak dengan SD dengan klinis mendengkur yaitu $12,9 \mathrm{kali} / \mathrm{jam} .{ }^{22}$

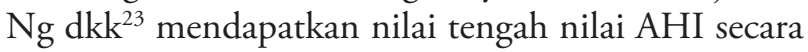
bermakna lebih tinggi pada kelompok SD, yaitu 1,8 kali/jam (jarak interkuartil 0,4-7,10) dibandingkan kelompok kontrol $0,5 \mathrm{kali} / \mathrm{jam}$ (jarak interkuartil 0,00-2,03); $p=0,041$. Lin $\mathrm{dkk}^{26}$ melakukan studi kasus kontrol pada 49 anak dengan SD yang mengalami OSA dengan kontrol populasi anak umum dengan jenis kelamin dan usia sama yang mengalami OSA. Hasil penelitian tersebut melaporkan bahwa anak dengan SD memiliki OSA derajat lebih berat dibandingkan total 279 anak yang dirujuk untuk pemeriksaan PSG. Nilai AHI tidak dapat dijadikan parameter tunggal untuk evaluasi SDB. ${ }^{27}$ Parameter respiratori lain yang didapatkan dari hasil poligrafi pada penelitian ini yaitu indeks apnea (AI), indeks resistensi, saturasi dasar, saturasi terendah, dan desaturasi terendah.

Ronen $\mathrm{dkk}^{28}$ melaporkan usia dan jenis kelamin berpengaruh terhadap OSA. Hal tersebut berdasarkan laporan bahwa anak lelaki dan perempuan pra-pubertas memiliki panjang jalan napas yang serupa. Namun, anak lelaki yang telah memasuki masa pubertas akan memiliki jalan napas yang lebih panjang yang berhubungan dengan peningkatan kolaps jalan napas sehingga OSA lebih dominan pada lelaki. ${ }^{29}$ Pada penelitian ini, usia dan jenis kelamin tidak berpengaruh terhadap terjadinya OSA. Perbedaan ini dapat disebabkan rerata usia pada penelitian ini adalah 7,5 tahun $( \pm 3,48)$ dan sebagian besar subjek berusia di bawah 8 tahun $(64,3 \%)$. Hasil penelitian ini sejalan dengan hasil penelitian oleh Fitzgerald $\mathrm{dkk}^{22}$ pada anak dengan SD rerata usia 4,9 tahun, yaitu tidak ada hubungan antara usia dan AHI. Austeng $\mathrm{dkk}^{24}$ tidak menemukan hubungan antara OSA dengan jenis kelamin pada subjek anak dengan SD usia 8 tahun.

Penelitian ini tidak menemukan hubungan antara gizi lebih dan obesitas dengan OSA. Penelitian ini menyimpulkan hal yang berbeda dengan sebagian besar penelitian serupa yang pernah dilakukan, yaitu hubungan yang berbanding lurus antara obesitas dengan AHI pada pasien OSA-SD. ${ }^{21,23,30}$ Penjelasan perbedaan ini dapat disebabkan perbedaan kelompok usia sehingga jumlah kelompok yang mengalami obesitas hanya sedikit. Jumlah obesitas yang sedikit disebabkan rerata usia penelitian ini 7,5 tahun. Penelitian ini lebih banyak subjek usia 3-8 tahun $(66,7 \%)$, sedangkan individu dengan SD mengalami peningkatan risiko obesitas ketika beranjak dewasa. ${ }^{31}$ Penelitian lain yang menggunakan subjek anak berusia kurang dari 8 tahun tidak menemukan hubungan antara obesitas dengan OSA. ${ }^{20,22,27,32}$

Supriyatno $\mathrm{dkk}^{33}$ melaporkan prevalensi mendengkur 31,6\% pada anak usia 5-13 tahun (habitual snoring sebesar 5,2\% dan occasional snoring 26,4\%). Hasil penelitian ini menunjukkan mendengkur lebih sering dialami anak dengan SD dibandingkan populasi umum. Penelitian ini menemukan hubungan bermakna antara keluhan habitual snoring dengan OSA baik pada analisis univariat maupun multivariat. Hal tersebut sesuai dengan penelitian Fitzgerald dkk, ${ }^{22}$ pada 33 anak dengan SD dengan usia rerata 4,9 tahun. Fitzgerald dkk melaporkan $97 \%$ anak dengan SD yang mendengkur juga memiliki OSA. Prevalensi yang tinggi tersebut disebabkan subjek penelitian adalah anak dengan SD yang mendengkur, sedangkan pada penelitian ini tidak dibatasi anak dengan SD yang mendengkur. Pada penelitian ini, 88,9\% subjek mengalami habitual snoring dan OSA. Maris $\mathrm{dkk}^{25}$ melaporkan prevalensi OSA secara bermakna lebih sering terjadi pada kelompok mendengkur $(75,7 \%)$ dibandingkan pada kelompok tanpa mendengkur $(53,8 \%)$. Subjek pada kelompok mendengkur mengalami OSA yang lebih berat dengan nilai tengah AHI 5,7 kali/jam (1,7-13,8) dibandingkan kelompok tanpa mendengkur yaitu 2,2 kali/jam (0,8-8).

Literatur mengenai insiden alergi pada anak dengan SD hanya sedikit dan menunjukkan probabilitas alergi yang rendah. ${ }^{34}$ Mannan $\mathrm{dkk}^{35}$ melakukan studi kasus kontrol pada 39 anak dengan SD usia 0,7 hingga 17 
tahun, prevalensi uji tusuk kulit positif hanya $18 \%$ pada anak dengan SD, dibandingkan 54\% pada kelompok kontrol. Penelitian tersebut menyimpulkan bahwa gejala rinitis kronis, otitis media berulang, dan OSA yang dialami oleh anak dengan SD tidak berhubungan dengan faktor lingkungan atau alergi, tetapi lebih disebabkan oleh anatomi yang khas pada SD. Penelitian ini tidak menemukan hubungan yang bermakna antara rinitis alergi dengan OSA. Hal tersebut sesuai dengan penelitian oleh $\mathrm{Ng} \mathrm{dkk}^{23}$ yang melaporkan kelompok kontrol OSA non-SD memiliki rinitis alergi secara bermakna lebih tinggi dari kelompok kasus OSA-SD.

Penyempitan jalan napas yang disebabkan efek ukuran tonsil dapat menyebabkan gambaran pola napas abnormal pada uji tidur. Penelitian mengenai prevalensi hipertrofi tonsil pada anak usia sekolah dasar di Turki sebesar $11 \% .{ }^{36}$ Hasil penelitian ini menunjukkan hipertrofi tonsil dan adenoid lebih sering dialami anak dengan SD dibandingkan populasi anak umum. Hal ini sejalan dengan Lal $\mathrm{dkk}^{13}$ yang melaporkan hipertrofi tonsil 10 kali lebih sering pada anak dengan SD dibandingkan anak OSA non-SD.

Penelitian ini menemukan hubungan yang bermakna antara hipertrofi tonsil dengan OSA. Hasil penelitian ini sejalan dengan penelitian oleh Kang dkk ${ }^{37}$ yang melaporkan bahwa AHI berbanding lurus dengan ukuran tonsil pada semua kelompok usia. Shires $\mathrm{dkk}^{30}$ melaporkan korelasi positif antara ukuran tonsil dan AHI pada 52 subjek anak dengan SD dengan rerata usia 9,3 tahun. Miguel $\mathrm{dkk}^{20}$ melaporkan hubungan bermakna antara hipertrofi tonsil dengan AHI. Saat dilakukan analisis lebih lanjut, tidak ditemukan hubungan bermakna antara hipertrofi tonsil dan OSA. Berdasarkan penelitian oleh $\mathrm{Ng} \mathrm{dkk}^{23}$ tonsil bukanlah faktor risiko OSA pada anak, baik pada kelompok kasus OSA-SD maupun kelompok kontrol OSA-non-SD. Penelitian Maris $\mathrm{dkk}^{25}$ yang melibatkan 216 anak dengan SD dan berhasil dilakukan pemeriksaan PSG pada 122 anak dengan nilai tengah usia 5 tahun $(2,8-10,5)$ melaporkan tidak ada hubungan antara ukuran tonsil dan AHI.

Hipertrofi adenoid menyebabkan beberapa komorbid, seperti OSA, otitis serosa kronis, dan sinusitis. ${ }^{38}$ Penelitian ini menemukan adanya hubungan yang bermakna antara pembesaran kelenjar adenoid dengan OSA. Hasil penelitian ini sejalan dengan sebagian besar penelitian yang menyatakan terdapat hubungan antara hipertrofi adenoid dengan OSA. ${ }^{37,39,40} \mathrm{Hwang} \mathrm{dkk}^{27}$ melakukan penelitian kegunaan ukuran adenotonsilar untuk melihat derajat berat OSA dan mendapatkan hanya ukuran adenoid (menggunakan ANR) yang berhubungan dengan penurunan saturasi oksigen pada kelompok OSA, terutama pada kelompok OSA sedang hingga berat.

\section{Kesimpulan}

Prevalensi OSA pada anak sindrom Down adalah $61,9 \%$. Faktor yang berhubungan terhadap OSA pada anak sindrom Down adalah habitual snoring dan hipertrofi adenoid.

\section{Saran}

Perlunya edukasi mengenai OSA kepada orangtua anak dengan SD mengingat tingginya prevalensi OSA. Pada anak sindrom Down dengan keluhan mendengkur dan hipertrofi adenoid maka dapat diberikan tata laksana untuk OSA. Perlunya dilakukan penelitian lebih lanjut melibatkan multisenter dan lebih banyak rentang usia remaja untuk mengetahui hubungan faktor obesitas terhadap terjadinya OSA pada anak dengan SD.

\section{Daftar pustaka}

1. Marcus CL, Brooks LJ, Draper KA, Gozal D, Halbower AC, Jones J, dkk. Diagnosis and management of childhood obstructive sleep apnea syndrome. Pediatrics 2012;130:57

2. Chhangani BS, Melgar T, Patel D. Pediatric obstructive sleep apnea. Indian J Pediatr 2010;77:81-5.

3. Bhatt SP, Guleria R, Kabra SK. Obstructive sleep apnea syndromes in children. Int J Med Med Sci 2014;1:14-20.

4. Supriyatno B, Deviani R. Obstructive sleep apnea syndrome pada anak. Sari Pediatri 2005;7:77-84.

5. Chng SY, Goh DYT, Wang XS, Tan TN, Ong NB. Snoring and atopic disease: a strong association. Pediatr Pulmonol 2004;38:210-16.

6. Mai CT, Kucik JE, Isenburg J, Feldkamp ML, Marengo LK, Bugenske EM, dkk. National birth defect prevention N. Selected birth defects data from population-based birth defects surveillance program in the United States, 2006 to 2010: featuring trismoy conditions. Birth Defects Res A Clin Mol Teratol 2013;97:709-25.

7. Badan Penelitian dan Pengembangan Kesehatan Kementerian Kesehatan Republik Indonesia (RI). Riset kesehatan dasar (RISKESDAS) 2013. Jakarta: Kementerian Kesehatan RI; 2013. 
8. Chan J, Edman JC, Koltai PJ.Obstructive sleep apnea in children. Am Fam Physician 2004;69:1147-54.

9. Bull MJ. The Committee on Genetics. Health supervision for children with Down syndrome. Pediatrics 2011;128:393-406.

10. Chin CJ, Khami MM, Husein M.A general review of the otolaryngologic manifestation of Down syndrome. Int J Pediatr Otorhinolaryngol 2014;78:899-904.

11. Shott S, Amin R, Chini B, Heubi C, Hotze S, Akers R. Obstructive sleep apnea: should all children with Down syndrome be tested? Arch Otolaryngol Head Neck Surg 2006;132: 432-6.

12. Shoot $S R$. Down syndrome : common otolaryngologic manifestation. Am J Med Genet C Semin Med Genet 2006;142:131-40.

13. Lal C, White DR, Joseph JE, Bakergem K, LaROsa A. Sleep-disordered breathing in Down syndrome. Chest 2015;147:570-9.

14. Beck S, Marcus CL. Pediatric polisomnography. Sleep Med Clin 2009;4:393-406.

15. Capdevila OS, Kheirandish-Gozal L, Dayyat E, Gozal D. Pediatric obstructive sleep apnea: complication, management, and long term outcome. Proc Am Thorac Soc 2008;5:274-82.

16. Breslin J, Spano G, Bootzin R, Anand P, Nadel L, Edgin J. Obstructive sleep apnea syndrome and cognition in Down syndrome. Dev Med Child Neurol 2014;56:657-64.

17. Baumer N, Davidson EJ. Supporting a happy, healthy adolescence for young people with Down syndrome and other intellectual disabilities: recommendation for clinicians. Curr Opin Pediatr 2014;26:428-34.

18. Muzumdar H, Arens R. Diagnostic issues in pediatric obstructive sleep apnea. Proc Am Thorac Soc 2008;5:263-73.

19. Lumeng JC, Chervin RD. Epidemiology of pediatric obstructive sleep apnea. Proc Am Thorac Soc 2008;5:242-52.

20. Miguel-Diez J, Villa-Asensi JR, Ivarez-Sala AJL. Prevalence of sleep-disordered breathing in children with Down syndrome: polygrapic findings in 108 children. Sleep 2003;26:1006-9.

21. Dyken ME, Lin-Dyken DC, Poulton S, Bridget Z, Sedars E. Prospective polysomnographic analysis of obstructive sleep apnea in Down syndrome. Arch Pediatr Adolesc Med 2003;157:655-60.

22. Fitzgerald DA, Paul A, Richmond C. Severity of obstructive apnoea in children with Down syndrome who snore. Arch Dis Child 2007;92:423-5.

23. Ng DK, Hui HN, Chan Ch, Kwok LL, Chow PY, Cheung JM, dkk. Obstructive sleep apnea in children with Down syndrome. Singapore Med J 2006;47:774-9.

24. Austeng ME, Overland B, Kvaerner KJ, Anderson EM, Axelsson S, Abdelnoor M, dkk. Obstructive sleep apnea in younger school children with Down syndrome. J Pediatr Otorhinolaryngol 2014;1:1-4.

25. Maris M, Verhulst S, Wojciechowski M, Heyning PV,
Boudewyns A. Prevalence of obstructive sleep apnea in children with Down syndrome. Sleep 2016;39:699-704.

26. Lin SC, Davey MJ. Horne RS. Nixon GM. Screening for obstructive sleep apnea in children with Down syndrome. J Pediatr 2014;165:117-22.

27. Hwang SH, Guilleminault C, Park CS, Kim TW, Hong SC. Usefullness of adenotonsilar size for prediction of severity of obstructive sleep apnea and flow limitatation. Otolaryngology Head and Neck Surg 2013;149:327-34.

28. Ronen O, Malhotra A, Pillar G. Influence of gender and age on upper-airway length during development. Pediatrics 2007;120:1028-34.

29. Katz ES, Ambrosia CM. Pathophysiology of pediatric obstructive sleep apnea. Proc Am Thorac Soc 2008;5:253-62.

30. Shires CB, Anold SL, Schoumacher RA, Dehoff GW, Donepudi SK, Stocks RM. Body mass index as an indicator of obstructive sleep apnea in pediatric Down syndrome. Int J Pediatr Otorhinolaryngol 2010;74:768-72.

31. Basil SJ, Santoro SL, Martin LJ, Healy KW, Chini BA, Saal HM. Retrospective study of obesity in children with Down syndrome. J Pediatr 2016;173:143-8.

32. Bassel JL. Sleep profiles in children with Down syndrome. Am J Med Genet A 2015;167:1830-5.

33. Supriyatno B, Deviani R, Tumbelaka A, Kariani EBK, Rahajoe NN. . Characteristics and risk factors of snoring and the prevalence of suspected obstructive sleep apnea in children. Pediatr Indones 2005;45:40-5.

34. Lopez FM. Pediatrics, Down's syndrome and allergic disease. Rev Med Int Sindr Down 2011:15:8-13.

35. Mannan SE. Yousef E. Hossain J. Prevalence of positive skin prick test result in children with Down syndrome : a casecontrol study. Ann Allergy Asthma Immunol 2009;102:205-9.

36. Kara CO, Ergin H, Kocak G, Kilic I, Yurdakul M. Prevalence of tonsillar hypertrophy and associated oropharyngeal symptoms in primary school children in Denizli, Turkey. Int J Pediatr Otorhinolaryngol 2002;66:175-9.

37. Kang KT, Chou CH, Weng WC, Lee PL, Hsu WC. Associations between adenotonsilar hypertrophy, age, and obesity in children with obstructive sleep apnea. PlosOne 2013;8:1-8.

38. Evcimik MF, Dogru M, Cirik AA, Nepesov MI. Adenoid hypertrophy in children with allergic disease and influential factor. Int J Pediatr Otorhinolaryngol 2015;79:694-7.

39. Tagaya M, Nakata S, Yasuma F, Miyazaki S, Sasaki F, Morigana M, dkk. 2012 Relationship between adenoid size and severity of obstructive sleep apnea in preschool children. Int J Pediatr Otorhinolaryngol 2012;76:1827-30.

40. Somayaji K.S. Rajeshwari A, Mahaveera J. Significance of adenoid nasopharyngeal ratio in the assessment of adenoid hypertrophy in children. Res Otolaryngol 2012;1:1-5. 